\title{
GAMBARAN PENGETAHUAN REMAJA MENGENAI BAHAYA ALKOHOL DENGAN STROKE
}

\author{
${ }^{1}$ Edward Khosuma \\ ${ }^{2}$ Mieke Kembuan \\ ${ }^{2}$ Winifred Karema
}

\author{
${ }^{1}$ Kandidat SkripsiFakultasKedokteranUniversitas Sam Ratulangi Manado \\ ${ }^{2}$ Bagian/SMF Neurologi Fakultas Kedokteran Universitas Sam Ratulangi Manado \\ Email: paai_manado@yahoo.com
}

\begin{abstract}
Stroke or brain circulatory disorders as a major problem in the field of neurology. Not only the number of events is increasing, but also that interfere kemungkinasekuel for a long time, and decreased morbidity and increased mortality. During this time, most people just assume that strokes only happen to people in adulthood or old. In fact, stroke can also occur in teenagers. This study aims to describe the level of knowledge of adolescents about the dangers of alcohol and stroke. This is a descriptive study using survey method.The sample were 81 adolescents aged 15-19 years, whose enrolling study at Kristen 1 Senior High School and Manado Internasional School.Datas were collected by questionnaire and short interview. There are $81 \%$ of samples at Sonder Christian Senior High School and $80 \%$ of samples atManado International School knew the definition of alchohol. 88\% of samples at Sonder Christian 1 Senior High School also 80\% of samples at Manado International Schoolknew the definition of stroke.59\% of sampelsat Sonder Christian Senior High Schooland 61\% of samples at Manado International School knew alchohol was one of the cause in stroke incident. Conclusion: More than $50 \%$ of sampelsat both schoolscategorized in the group of people who knew the danger of alchohol in relation with stroke.
\end{abstract}

Keywords: Adolelescents, knowledge, alchohol, stroke

\begin{abstract}
Abstrak: Stroke atau gangguan peredaran darah otak merupakan problem utama dibidang neurologi. Bukan hanya angka kejadiannya yang makin meningkat, tapi juga kemungkinan tersisanya sekuel yang menggangu untuk waktu yang lama, serta menurunnya morbiditas serta meningkatnya mortalitas. Selama ini, kebanyakan orang hanya menganggap bahwa stroke hanya dialami oleh mereka pada usia dewasa atau tua. Padahal, stroke juga bisa terjadi pada remaja. Penelitian ini bertujuan untuk mengetahui gambaran tingkat pengetahuan remaja mengenai bahaya alkohol dengan stroke. Penelitian ini bersifat deskriptif dengan metode survei.Sampel adalah 81 remaja berusia 15-19 tahun yang bersekolah di SMA Kristen 1 Sonder dan SMA MIS. Data didapatkan lewat kuesioner dan wawancara singkat. Sebanyak 81\% siswa SMA Kr 1 Sonder dan 80\% siswa SMA MIS Manado menjawab ya mereka tahu alkohol itu apa. 88\% SMA Kr 1 Sonder dan 80\% SMA MIS Manado menjawab mereka sudah tahu tentang stroke, dan 59\% SMA Kr 1 Sonder serta 61\% SMA MIS Manado sudah mengetahui bahwa alkohol merupakan salah satu penyebab stroke.Simpulan: lebih dari50\% responden dikedua sekolah paling banyak dikategori ya mereka tahu mengenai bahaya alkohol dengan stroke.
\end{abstract}

Kata kunci: Remaja, pengetahuan, alkohol, stroke

Stroke atau ganguan peredaran darah otak merupakan problem utama dibidang neurologi. Bukan hanya angka kejadiannya yang makin meningkat, tapi juga kemungkinan tersisanya sekuel yang menggangu untuk waktu yang lama, serta 
menurunnya morbiditas serta meningkatnya mortalitas. ${ }^{1}$

Selamaini, kebanyakan orang menganggap bahwa stroke hanya dialami oleh orang usia dewasa atau tua. Padahal, stroke juga bisa terjadi pada remaja. ${ }^{2}$

Di Amerika Serikat setiap tahunnya terdapat sekitar 200.000 kasus kematian yang disebabkan oleh stroke. Stroke merupakan penyebab kematian ketiga di negara ini. Sekitar setengah juta orang Amerika setiap tahunnya mengalami gangguan pembuluh darah akut. Sekitar $50 \%$ dari semua orang dewasa yang dirawat pada rumah sakit syaraf disebabkan oleh penyakit pembuluh darah ${ }^{3,4}$

Di Indonesia diperkirakan setiap tahunnya terjadi 500.000 penduduk terkena serangan stroke, sekitar 2,5\% atau 125.000 orang meningal, dan sisanya cacat ringan maupun berat. Faktor resiko terjadinya stroke antara lain hipertensi, kolesterol arteriosklerosis, ganguan jan-tung, DM, riwayat stroke dalam keluarga, merokok, usia, makanan tidak sehat, alkohol, kurang olahraga, kontrasepsi oral, obese dan stress. ${ }^{3,5}$

Sebuah meta-analisis terhadap 35 penelitian dari tahun 1966 hingga 2002 melaporkan bahwa dibandingkan dengan bukan pengguna alkohol, individu yang mengkonsumsi kurang dari $12 \mathrm{~g}$ per hari (satu minuman standar) alkohol memiliki adjusted RR yang signifikan lebih rendah untuk stroke iskemik (RR:0.80; 95\% Cl:0.67 hingga 0.96), demikian juga individu yang mengkonsumsi 12 hingga $24 \mathrm{~g}$ per hari (satu hingga dua standar minum) alkohol (RR:0.72; 95\% Cl:0.57 hingga 0.91). Tetapi individu yang mengkonsumsi alkohol lebih dari 60g per hari memiliki adjusted RR untuk stroke iskemik yang secarasignifikanlebihtinggi (RR:1.69; 95\% Cl: 1.3 hingga 2.1). ${ }^{6}$

Dalamsuatustudiobservasional, ditujukan bahwa konsumsi wine dalam intensita sringgan hingga sedang dapat berkaitan dengan penurunan resiko stroke iskemik. Sedangkan pada seseorang yang mengkonsums ialkohol dengan berlebihan dapat meningkatkan resiko stroke. ${ }^{6}$
Pengaruh mengkonsumsi alkohol dalam jangka waktu panjang dapat menurunkan Nitric Oxide Synthase-dependent (NOS) terkait dengan respon arteriole yang belum jelas mekanisme terjadinya. Mengkonsumsi alkohol dalam waktu lama memberikan konstribusi pada patogenesis beberapa penyakit kardiovaskuler, termasuk kardiomiopati, hipertensi sistemik, aritmia, stroke hemoragik dan non hemoragik. Efek dari peminumalkohol berat pada stroke hemoragik dimediasi oleh peningkatan tekanan darah. ${ }^{7}$

Tampaklah bahwa stroke merupakan masalah serius yang dialami banyak orang, dengan alkohol sebagai salah satu faktor resiko apalagi di kalangan remaja yang sekarang kebanyakan suka mengkonsumsi alkohol tanpa mengetahui dampak dari alkohol tersebut. Hal inilah yang mendorong penulis untuk mengetahui gambaran pengetahuan remaja mengenai bahaya alkohol dengan stroke.

\section{METODE}

Penelitian ini bersifat deskriptif yang dilaksanakan dengan metode survei. Pengambilan data dilaksanakan selama bulan November di SMA Kristen 1 Sonderdan SMA Manado International School. Sampel berjumlah 81 orang siswakelas XII dengan menggunakan metode total sampling.

Variabel yang diteliti merupakan pengetahuan siswa/remaja mengenai bahaya alkohol dengan stroke. Data penelitian didapatkan lewat kuesioner yang dibagikan serta wawancara singkat.

\section{HASIL DAN PEMBAHASAN}

Seluruh responden ini berjumlah 81 orang adalah remaja yang berusia 15-19 tahun dan pria berjumlah 37 orang dan wanita berjumlah 44 orang. Berdasarkan observasi penulis selama melakukan penelitian mendapatkan bahwa di SMA Kr 1 sonder siswa kelas XII lebih banyak siswa berjenis kelamin pria dengan jumlah 17 orang sedangkan wanita berjumlah 15 orang. SMA MIS manado siswakelas XII 
lebih banyak siswa berjenis kelamin wanita berjumlah 29 orang dan pria berjumlah 20 orang. Rata-rata umursiswa di kedua sekolah yang berada di kelas XII adalah 17 tahun, di SMA Kr 1 sonder $75 \%$ yang berumur 17 tahundan di SMA MIS 65\% berumur 17 tahun.

Berdasarkan hasil penelitian yang didapat bahwa pengetahuan tentang informasi berbagai jenis minuman beralkohol dan pengaruh minuman beralkohol itu sendiri paling banyak pada kategori ya tahu. Hal ini disebabkan oleh banyaknya pemberian informasi mengenai bahaya minuman beralkohol. Pada saat peneliti membagikan kuesioner, responden di kedua sekolah tidak terlihat bingung dan mengerti mengenai bahaya alkohol dengan stroke. Walaupun ada masih ada yang berpengetahuan buruk mengenai bahaya alkohol dengan stroke kita kembalikan kepada orang tua, masyarakat desa dan tenaga medis untuk meningkatkan informasi mengenai bahaya alkohol dengan stroke.

Tabel 1. Distribusi karakteristik umur responden.

\begin{tabular}{cccccccc}
\hline No & Umur & $\begin{array}{c}\text { SMA } \\
\text { Kr }\end{array}$ & MIS & N & $\begin{array}{c}\text { \% SMA } \\
\mathbf{K r}\end{array}$ & \% MIS & $\begin{array}{c}\text { \% } \\
\text { Total }\end{array}$ \\
\hline $\mathbf{1}$ & & & & & & & \\
$\mathbf{2}$ & 15 & 0 & 1 & 1 & 0 & 2 & 1 \\
$\mathbf{3}$ & 16 & 5 & 14 & 19 & 16 & 29 & 23 \\
$\mathbf{4}$ & 17 & 24 & 32 & 56 & 75 & 65 & 69 \\
\hline & 18 & 3 & 2 & 5 & 9 & 4 & 6 \\
\hline
\end{tabular}

Tabel 2. Sumber informasi siswa mengenai alkohol dengan stroke.

\begin{tabular}{cccccccc}
\hline No & $\begin{array}{c}\text { Dari mana anda mendapatkan } \\
\text { pengetahuan mengenai alkohol } \\
\text { dengan stroke }\end{array}$ & $\begin{array}{c}\text { SMA } \\
\text { Kr }\end{array}$ & MIS & N & $\begin{array}{c}\text { \% } \\
\text { SMA Kr }\end{array}$ & $\begin{array}{c}\text { \% } \\
\text { MIS }\end{array}$ & $\begin{array}{c}\text { \% } \\
\text { Total }\end{array}$ \\
\hline $\mathbf{1}$ & Penyuluhan/Posyandu & 12 & 0 & 12 & 34 & 0 & 14 \\
$\mathbf{2}$ & Tenaga medis (Dokter, Bidan) & 0 & 3 & 3 & 0 & 6 & 3 \\
$\mathbf{3}$ & Pengalaman & 9 & 12 & 21 & 26 & 23 & 24 \\
$\mathbf{4}$ & Media cetak & 2 & 9 & 11 & 6 & 17 & 13 \\
$\mathbf{5}$ & Media elektronik & 12 & 29 & 41 & 34 & 55 & 47 \\
\hline & Jumlah & $\mathbf{3 5}$ & $\mathbf{5 3}$ & $\mathbf{8 8}$ & $\mathbf{1 0 0}$ & $\mathbf{1 0 0}$ & $\mathbf{1 0 0}$ \\
\hline
\end{tabular}

Tabel 3. Pengetahuan siswa mengenai alkohol dan stroke.

\begin{tabular}{cccccccc}
\hline & & & & & $\begin{array}{c}\text { \% } \\
\text { SMA }\end{array}$ & \% & \% \\
& & SMA & & & SMr \\
& & Kr & MIS & N & Kr & MIS & Total \\
\hline Stroke bisa terjadi pada & Ya & 21 & 38 & 59 & $66 \%$ & $78 \%$ & $73 \%$ \\
remaja, dewasa, usia lanjut & Tidak & 11 & 11 & 22 & $34 \%$ & $22 \%$ & $27 \%$ \\
& & 32 & 49 & 81 & $100 \%$ & $100 \%$ & $100 \%$ \\
\hline Alkohol merupakan salah satu & Ya & 19 & 30 & 59 & $59 \%$ & $61 \%$ & $60 \%$ \\
faktor penyebab stroke & Tidak & 13 & 19 & 22 & $41 \%$ & $39 \%$ & $40 \%$ \\
& & 32 & 49 & 81 & $100 \%$ & $100 \%$ & $100 \%$ \\
\hline
\end{tabular}


Berdasarkan penelitian yang didapat bahwa di kedua sekolah mendapatkan informasi mengenai bahaya alkohol dengan stroke paling banyak dari media elektronik dan media cetak. Di SMA Kr 1 Sonder 34\% mendapatkan informasi dari media elektronik dan SMA MIS Manado 55\% mendapatkan informasi mengenai bahaya alkohol dengan stroke dari media elektronik. Di SMA Kr 1 Sonder 26\% pengetahuan mereka mengenai bahaya alkohol dengan stroke didapatkan dari penyuluhan sedangkan di SMA MIS Manado tidak mendapatkan informasi mengenai bahaya alkohol dengan stroke dikarenakan tidak pernah diadakan penyuluhan mengenai bahaya alkohol dengan stroke sama sekali. Di kedua sekolah ditanyakan apabila setuju diadakan penyuluhan mengenai bahaya alkohol dengan stroke dan paling banyak menjawab di kategori ya setuju diadakan penyuluhan mengenai bahaya alkohol dengan stroke di sekolah. Berdasarkan asumsi peneliti, di jaman sekarang ini media elektronik sangat berperan penting baik dalam edukasi mengenai bahaya alkohol dengan stroke ini terbukti informasi mengenai bahaya alkohol dengan stroke didapatkan melalui media eletronik tapi peranan orang tua tidak kalah penting dalam mengarahkan anak-anak mereka dalam pergaulan agar menjauhi alkohol. Ini dikarenakan di masa remaja seperti mempuyai sikap ingin mencoba hal-hal baru dan dalam masa mencari jati diri mereka.

Berdasarkan hasil penelitian yang di dapatkan di SMA Kr 1 Sonder kebanyakan siswa sudah tahu alkohol dan stroke itu seperti apa, di SMA Kr 1 sonder 81\% siswa tahu alkohol itu apa dan 88\% siswa sudah tahu mengenai alkohol. Di SMA MIS manado $80 \%$ siswa sudah tahu mengenai alkohol dengan stroke. Sebagian responden menjawab tahu alkohol merupakan salah satu penyebab stroke, di SMA Kr 1 sonder 59\% yang tahu alkohol merupakan salah satu penyebab stroke dan SMA MIS manado $61 \%$ yang tahu alkohol merupakan salah satu penyebab stroke. Kebanyakan siswa di kedua sekolah sudah tahu bahwa stroke bisa terjadi pada remaja, dewasa, dan usia lanjut. Walaupun pengetahuan mengenai bahaya alkohol dengan stroke sudah baik dan mereka sudah tahu meminum alkohol yang berlebihan mempunyai dampak yang buruk bagi kesehatan, namun mereka masih saja mengkonsumsi minuman beralkohol. Hal ini disebabkan pengaruh lingkungan pergaulan serta kemudahan dalam memperoleh minuman beralkohol tersebut.

\section{SIMPULAN}

Berdasarkan penelitian mengenai tingkat pengetahuan remaja mengenai bahaya alkohol dengan stroke paling banyak dikategori ya tahu, ini bisa di lihat sebagian besar siswa di kedua sekolah sudah tahu bahwa alkohol merupakan salah faktor penyebab stroke. Pengetahuan sebagian siswa di kedua sekolah masih kurang di karenakan kurangnya informasi yang didapatkan dari penyuluhan dan tenaga medis mengenai bahaya alkohol dengan stroke.

\section{DAFTAR PUSTAKA}

1. Burdiarto G. Peran Antikoagulan Oral pada Pencegahan Stroke karena AF. Dalam: Neurologi Update: Buku Naskah Lengkap Konas Perdosi 2011. Edisi I. Yogyakarta: Pustaka Cendekia Press, 2011; h.253.

2. Wiwit S. Stroke dan Penanganannya. Cetakan I. Depok: Katahati; 2010. hal: 28.

3. Wiratmoko H. Deteksi Dini Serangan dan Penanganan Stroke Di Rumah. [Diakses: 16 Oktober 2012]. Dunduh dari: http://isjd.pdii.lipi.go.id/admin/jurnal/ 22103844_2085-028X.pdf.

4. Karina T. Hubungan Subtipe Stroke Iskemik dengan Kadar High Sensitive Creactive Protein. [Diakses: 16 Oktober 2012]. Diunduh dari: http://pasca.unand. ac.id/id/wp-content/uploads/2011/09/

HUBUNGAN-SUBTIPE-STROKEISKEMIK-DENGAN-KADAR1.pdf.

5. Susilo H. The Powerful Blood Pressure Reductionin Hypertensive Stroke Patients With Single Pill Combination Of Valsartan And Amilodipine. In: Neurologi Update: 
Buku Naskah Lengkap Konas Perdosi 2011. $1^{\text {st }}$ edition. Yogyakarta: Pustaka Cendekia Press, 2011; p.238.

6. Gofir A. Manajemen Stroke. Edisi II. Yogyakarta: Pustaka Cendekia Press, April 2011; h.86-7.

7. Widiyanto P, Ekanto B. Perubahan
Disfungsi Endotel Aorta pada Tikus Galur Putih Remaja yang Terpapar Alkohol Terhadap Pemberian Curcumin. [Diakses: 16 Oktober 2012]. Diunduh dari: http://digilib.stikesmuhgombong.ac.id /files/disk1/23/jtstikesmuhgo-gdlpuguhwidiy-1132-2-hal.71--2.pdf. 